\title{
Exchange Rates and Portfolio Rebalancing: Evidence from Emerging Economies
}

\author{
Sorin Rizeanu ${ }^{1} \&$ Hao Zhang ${ }^{1}$ \\ ${ }^{1}$ Peter B. Gustavson School of Business, University of Victoria, Victoria, BC, V8W 2Y2, Canada \\ Correspondence: Hao Zhang, Peter B. Gustavson School of Business, University of Victoria, Victoria, BC, V8W \\ 2Y2, Canada. Tel: 1-250-853-3871. E-mail: hzhang@uvic.ca
}

Received: December 17, 2012

Accepted: January 7, $2013 \quad$ Online Published: January 8, 2013

doi:10.5539/ijef.v5n2p15

URL: http://dx.doi.org/10.5539/ijef.v5n2p15

\begin{abstract}
This paper tests the portfolio rebalancing model of Hau and Rey (2006) based on a sample of 23 emerging economies for the period of 1994-2010. We find that the exchange rate returns in emerging economies are significantly and positively correlated with excess emerging stock market returns vis-à-vis the United States, indicating that portfolio rebalancing does not characterize the exchange rate movements for emerging economies. Our findings are strongly supported at daily and monthly frequencies, and are robust to cross-market correlations, different stock market capitalizations, alternative exchange rate systems, capital controls and financial crises.
\end{abstract}

Keywords: exchange rates, equity returns, portfolio rebalancing, emerging markets

\section{Introduction}

Recent exchange rate theories have advanced beyond the scope of traditional macroeconomic theory. In their seminal work, Hau and Rey (2006) suggest a dynamic relationship between exchange rates and stock market returns under incomplete foreign exchange risk trading. Focusing on short- and medium-run fluctuations, the authors show that exchange rates are significantly impacted by portfolio rebalancing following equity market innovations. In their model, investors hold equity risk and currency risk as a bundle. If a portfolio of domestic and international equity investments is optimally allocated, then a positive shock to foreign stock markets increases the risk of the portfolio. Investors sell part of their foreign portfolio holdings to reduce the exposure to currency risk, triggering order flows in the foreign exchange markets and driving down the exchange rate for the foreign currency. Therefore, portfolio rebalancing induces foreign currency depreciation following positive shocks in foreign equity markets, causing a negative correlation between exchange rates and stock market returns. This framework, based on the micro-foundation of foreign exchange markets, suggests that stronger equity markets should be associated with weaker currencies.

This paper extends Hau and Rey's (2006) analysis for a sample of 23 emerging market currencies across Asia, Latin America, Europe and Africa over the period 1994-2010. Our undertaking is motivated by notable dissimilarities between emerging and developed countries' currencies. First, emerging currencies constitute a substantial part of the currency trade, but hedging instruments in many of the emerging countries are limited and foreign purchases of stocks are often unhedged (Remsperger, 2007; Saxena \& Villar, 2008). Therefore, portfolio rebalancing should be an essential tool for managing currency risk in emerging market investments. Second, emerging economies often depart from the declared currency regime and may prevent the free movement of exchange rates (Calvo \& Reinhart, 2002; Edwards, 2007). Many emerging economies also impose capital controls to reduce pressure on their exchange rates (Edwards, 2007; Edwards \& Rigonbon, 2009; Baba \& Kokenyne, 2011; Magud et al., 2011). Therefore, the correlation structure between exchange rates and stock market returns predicted by Hau and Rey (2006) may be distorted in emerging economies. Third, emerging market currencies are more exposed to financial contagion and crises, resulting from inflation, currency attacks, systemic or financial distresses, and sovereign debt defaults (Reinhart, 2010), raising the question of how these shocks impacts the correlation between exchange rates and equity market returns. Fourth, emerging economies are on a more accelerated tempo of capital market development and integration into the world economy, thus being an excellent laboratory to study whether these factors affect the correlation structure suggested by Hau and Rey (2006). 
This study contributes to the understanding of the correlation structure between exchange rates and equity market returns, a central issue for international diversification and risk management (Campbell et al., 2010). We find that portfolio rebalancing does not characterize the exchange rate dynamics of emerging economies, as indicated by the positive and significant correlation between exchange rate returns and excess emerging stock market returns vis-à-vis the United States, at daily and monthly frequencies. Our results take into account cross-market correlations and are robust to emerging economies with different stock market capitalizations, alternative exchange rate systems, capital controls and financial crises.

This research is organized as follows: Section 2 reviews the literature on the correlation between exchange rates and stock market returns for emerging economies. Section 3 describes the methodology and data. Section 4 reports the results and Section 5 concludes the paper.

\section{Literature Review}

In the last decade, the share of emerging market currencies in global foreign exchange market turnover has increased to about 20\% (Bank for International Settlements, 2010). Large investors, such as pension funds in the United States and other developed economies have made emerging markets the main beneficiaries of their international diversification (Note 1).

In contrast to developed countries, many emerging market currencies are subject to foreign exchange convertibility restrictions and capital controls imposed by local authorities. Emerging market currencies are often thinly traded and associated with high inflation and volatility. However, the offer for derivative products for risk management in emerging market currencies is limited. For example, traditional forward contracts are not available for many Latin American and Asian currencies, such as Brazil, Chile, China, Columbia, India, Indonesia, Korea, Malaysia, Peru and Taiwan. These currencies trade in non-deliverable forward markets, where $60-80 \%$ of the estimated trading volume relates to speculation (Lipscomb, 2005). Given the growing importance of capital flows to emerging economies and lack of alternative hedging instruments, portfolio rebalancing should be an essential tool for managing currency risk in emerging market investments. Hau and Rey (2006) find that portfolio rebalancing characterizes the exchange rate dynamics for 17 developed countries. Chaban (2009) finds that the portfolio rebalancing model does not hold for commodity currencies of Australia, Canada and New Zealand, suggesting that commodities prices, offsetting the fluctuations in exchange rates, may play a similar role to the terms of trade in risk sharing between commodity exporting and importing countries. Several issues arise when testing Hau and Rey (2006) model for emerging market currencies.

\subsection{Currency Regimes and Capital Controls}

Although portfolio rebalancing by international investors induces selling in the foreign exchange markets, substantial capital inflows generate upward pressure on emerging currencies. According to International Monetary Fund (IMF), the net capital flows, including portfolio flows and direct investments, account for about $3 \%$ of gross domestic product (GDP) for emerging economies, compared to about $2 \%$ of GDP for developed economies during 2002-2010 (IMF, 2011a, Figure 4.2). For the same period, the net portfolio equity flows to emerging economies account for about $1 \%$ of GDP, compared to about $0.5 \%$ of GDP for developed economies (IMF, 2011a, Figure 4.4). Substantial net equity inflows offset the exchange rate movements induced by portfolio rebalancing and may create positive correlations between exchange rates and stock market returns.

Capital controls and central bank interventions in the foreign exchange markets in 2000s aim to alleviate the upward pressure on emerging currencies by curbing speculative inflows (Edwards, 2007; Edwards \& Rigobon, 2009; Ostry et al., 2010; IMF, 2011b). The effect of such actions on exchange rates remains an open question. While early studies suggest that capital controls and central bank interventions have short-term effects on exchange rates (Magud et al., 2011), recent research indicates that these actions are ineffective in changing the trend for emerging currencies (Binici et al., 2009; Rincon \& Toro, 2010; Baba \& Kokenyne, 2011; Concha \& Galindo, 2011; Magud et al., 2011) (Note 2). Therefore, in contrast to developed economies, the correlation structure between exchange rates and excess emerging stock market returns is affected by several factors including the magnitude of net equity inflows to emerging economies, the impact of capital controls and central bank interventions on the foreign exchange markets, and the significance of portfolio rebalancing by international investors. A negative correlation indicates that portfolio rebalancing characterizes the exchange rate dynamics for emerging market currencies. A positive correlation suggests that other factors, such as substantial capital inflows, influence the exchange rates for emerging economies. 


\subsection{Financial Crises and Contagion}

Emerging economies and their currencies are more prone to boom and bust cycles (e.g., 1994 Mexican Tequila crisis, 1997 Asian flu and 1998 Russian default). As pointed out by Longin and Solnik (2001), Ang and Bekaert (2002), and Forbes and Rigobon (2002), the correlation structures for the boom and bust periods may differ due to higher volatilities during bear markets. Specifically, when foreign capital pushes into emerging markets during a boom period, portfolio rebalancing based on currency risk may be important for international investors, inducing negative correlations between exchange rates and emerging stock markets returns. During crisis periods, investors pull out or freeze their foreign investments amid dramatic downturns in the currency or stock markets, inducing positive correlations between exchange rates and stock markets returns.

The correlation structure for emerging market currencies can also be affected by contagion, that is, crises in the foreign exchange or equity markets in one country can spread to other countries. Investors suffering losses in one country may sell assets in other countries, triggering forced equity portfolio rebalancing (Forbes, 2004, Kaminsky et al., 2004). Contagion effects are pronounced across countries within a region (Calvo \& Reinhart, 1996; Froot et al., 2001, Bekaert et al., 2005b) and are related to such fundamental economic variables as interest rates, exchange rates, and equity market volatilities (Bae et al., 2003). Therefore, we expect cross-market correlations in our sample due to regional interdependence.

\subsection{Financial Market Developments and Integration}

Hau and Rey (2006) conjecture that the negative correlation structure should be more evident during periods of increasing equity market integration and for countries with higher degrees of capital market development. Since the mid-1990s, many emerging market countries have relaxed or removed restrictions on capital flows and opened their capital markets to international investors. The financial economics literature suggests that correlations between emerging and developed markets have increased in the last decades, and financial liberalization and integration reduce the cost of capital, spur growth, and offer significant diversification benefits to international investors (Bekaert \& Harvey, 1995, 1997, 2000; Henry, 2000; Bekaert et al., 2005a; Carrieri et al., 2007). In the process of integrating into world financial markets, international investors in emerging markets gain better access to liquidity, information flow, and risk management tools. We expect that, for our sample of emerging markets, the correlation between exchange rates and stock markets returns should be increasingly significant over time following the path of financial integration, and the correlations should be more significant for countries with greater capital market development, as measured by the ratio of stock market capitalization to GDP.

\subsection{Equity Flows and Exchange Rates}

A number of studies on cross-border capital flows focus on contemporaneous correlations between equity flows and equity returns in developed and emerging markets (Tesar \& Werner, 1994, 1995; Brennan \& Cao, 1997). The evidence indicates that international investors engage in positive feedback trading in foreign equity markets, that is, buying subsequent to positive returns and selling subsequent to negative returns (Bohn \& Tesar, 1996; Edelen \& Warner, 2001; Froot et al., 2001; Kim \& Wei, 2002; Griffin et al., 2004, 2007; Richards, 2005; Froot $\&$ Ramadorai, 2008). Therefore, positive feedback trading may induce positive correlations between equity market returns and exchange rates.

Previous studies on equity flows and exchange rates in emerging markets focus on the period around currency crises. Bailey et al. (2000) document a significant relation between the depreciation of Mexican peso and the price decline of Latin American mutual funds and American Depositary Receipts during 1994 Mexican peso crisis. Choe et al. (1999) find strong evidence of positive feedback trading by foreign investors in Korean equity markets before the 1997 Asian currency crisis, and show that herding disappeared during the crisis. Swanson and Lin (2003) find positive feedback trading for seven emerging Asian countries around the Asian currency crisis. These findings suggest that financial crises may be an important factor when assessing the correlation between exchange rates and equity market returns for emerging economies.

Fewer studies, however, have examined the dynamics between equity flows and exchanges rates over longer periods. Brooks et al. (2004) find that higher portfolio flows to US stocks are associated with appreciation of the US dollar against the euro and Japanese yen. Siourounis (2004) reports that the net equity flows to the United States from Japan, Germany, Switzerland and the United Kingdom are associated with US dollar appreciation. Hau and Rey (2006) predict that higher equity flows are associated with stronger currencies and provide significant supporting evidence based on US equity flows to 17 developed economies. Our tests, covering a 
16-year period, contribute to the literature on the relationship between US equity flows and exchange rates for emerging economies.

\section{Methodology and Data}

\subsection{Methodology}

We test the correlation between the exchange rate returns and the equity return differentials for emerging and US stock markets by focusing on Hau and Rey (2006) model:

$$
-F X R_{i, t}=\alpha_{i}+\beta_{i} \text { MSCI_Excess } i, t+\varepsilon_{i, t}
$$

where, $F X R_{i, t}$ is the exchange rate return calculated as the log difference of the spot exchange rates, which are in foreign currency units per US dollar. Following Hau and Rey (2006), we multiply $F X R_{i, t}$ by -1 when calculating the correlations and performing regression analyses. MSCI_Excess $i_{i, t}$ is the difference between the emerging market and US market MSCI returns, measured in the respective local currencies, $i$ refers to the emerging economies in our sample, $\alpha_{i}$ is the intercept, $\beta_{i}$ is the estimated coefficient, and $\varepsilon_{i, t}$ is the error term. A negative $\beta_{i}$ indicates that a stronger emerging stock market is associated with depreciation of the emerging currency, as predicted by Hau and Rey (2006). A positive $\beta_{i}$ indicates that a stronger emerging stock market is associated with appreciation of the emerging currency. It is well known that stock market returns and changes in exchange rates are stationary variables and OLS regressions can be applied to Equation 1. We perform this regression for each country in our sample and compute Newey-West (1987) standard errors to account for heteroskedasticity and autocorrelation. We correct for the correlations of the error terms across countries using seemingly unrelated regression (SUR) system to ensure that cross-market correlations do not affect our results.

\subsection{Data}

Our sample includes 21 countries in the MSCI Emerging Markets Index: Brazil, Chile, China, Colombia, the Czech Republic, Egypt, Hungary, India, Indonesia, Korea, Malaysia, Mexico, Morocco, Peru, the Philippines, Poland, Russia, South Africa, Taiwan, Thailand, and Turkey. To this initial sample, we add Hong Kong and Singapore. These newly industrialized countries play an important role in the regional economy (Frankel \& Poonawala, 2010). The final sample consists of 23 countries from a variety of geographical locations (Asia, Latin America, emerging Europe and Africa) and at different stages of financial market development. Our sample covers a variety of exchange rate systems, including independent floating (Brazil, Chile, Mexico, the Philippines, Poland, South Africa, South Korea and Turkey), managed floating (Columbia, the Czech Republic, Hungary, India, Indonesia, Malaysia, Peru, Russia, Singapore, Taiwan and Thailand) and pegged system (China, Egypt, Hong Kong and Morocco) (Note 3).

Spot exchange rates and the MSCI series are obtained from Datastream for the period January 1994 to November 2010. The spot exchange rates are WM/Reuters closing middle rates quoted against the US dollar. The MSCI series are in US dollars for the United States and in local currencies for the 23 countries studied.

Crisis data are obtained from Reinhart (2010). The crises index is the sum of seven dummy variables that take the value of one if in a given year the country confronts a currency crisis, inflation crisis, stock market crash, domestic sovereign debt, external sovereign debt crisis, or banking crisis, and zero otherwise. Table 1 reports the average of the yearly crisis index over the period 1994-2010.

Capital flow data (TIC) are obtained from the Board of Governors Federal Reserve System and are available on a monthly basis. Using these data, we calculate the net increase in foreign stock ownership by US residents, defined as net US purchases of foreign equities minus net foreign purchases of US equities. Following Hau and Rey (2006), we normalize net foreign stock ownership as the proportion of the average absolute level of increase in net foreign ownership by US residents over the previous 12 months.

Table 1 provides a summary of the data. The average daily foreign exchange returns vary between -0.0010 and 0.0010 , with the lowest in the Czech Republic and Singapore and the highest in Turkey. The MSCI daily excess emerging stock markets returns, relative to the United States, vary between -0.0030 and 0.0024 , with the lowest average values in China and the highest values in Brazil. Stock market capitalization to GDP, obtained from the World Bank, varies from 0.0090 for South Korea to 3.1530 for Hong Kong. The average yearly crisis index, varying between 1.76 and 0.18 , has the highest value for Turkey and the lowest value for Taiwan. 
Table 1. Summary statistics

\begin{tabular}{|c|c|c|c|c|c|c|c|c|}
\hline Country & Dates & Currency regime & $F X R$ Mean & $F X R \mathrm{SD}$ & $\begin{array}{l}M S C I \\
\text { Excess } \\
\text { Mean }\end{array}$ & $\begin{array}{l}\text { MSCI } \\
\text { Excess SD }\end{array}$ & $\begin{array}{l}\text { MCap/ } \\
\text { GDP }\end{array}$ & Crisis \\
\hline Brazil & Jul-94 & Independent & 0.0001 & 0.0099 & 0.0024 & 0.0234 & 0.328 & 1.18 \\
\hline Chile & Dec-93 & Independent & 0.0000 & 0.0058 & 0.0003 & 0.0127 & 0.947 & 0.35 \\
\hline China & Dec-93 & Peg & 0.0000 & 0.0062 & -0.0003 & 0.0223 & 0.270 & 0.88 \\
\hline Colombia & Dec-93 & Managed & 0.0002 & 0.0062 & 0.0005 & 0.0167 & 0.160 & 1.12 \\
\hline Czech & Dec-94 & Managed & -0.0001 & 0.0075 & 0.0001 & 0.0175 & 0.213 & $\mathrm{n} / \mathrm{a}$ \\
\hline Egypt & Dec-94 & Peg & 0.0001 & 0.0036 & 0.0004 & 0.0202 & 0.256 & 0.24 \\
\hline Hong Kong & Dec-93 & Currency Board & 0.0000 & 0.0003 & 0.0001 & 0.0183 & 3.153 & $\mathrm{n} / \mathrm{a}$ \\
\hline Hungary & Dec-93 & Target Zone & 0.0001 & 0.0078 & 0.0004 & 0.0203 & 0.182 & 0.88 \\
\hline India & Dec-93 & Managed & 0.0001 & 0.0033 & 0.0002 & 0.0190 & 0.342 & 0.71 \\
\hline Indonesia & Dec-93 & Managed & 0.0003 & 0.0156 & 0.0001 & 0.0219 & 0.239 & 1.59 \\
\hline Malaysia & Dec-93 & Managed & 0.0000 & 0.0080 & 0.0000 & 0.0185 & 1.822 & 0.65 \\
\hline Mexico & Dec-93 & Independent & 0.0003 & 0.0098 & 0.0005 & 0.0130 & 0.279 & 1.18 \\
\hline Morocco & Dec-94 & Peg & 0.0000 & 0.0049 & 0.0001 & 0.0146 & 0.279 & 0.24 \\
\hline Peru & Dec-93 & Managed & 0.0001 & 0.0030 & 0.0005 & 0.0180 & 0.218 & 0.65 \\
\hline Philippines & Dec-93 & Independent & 0.0001 & 0.0060 & 0.0001 & 0.0190 & 0.556 & 0.88 \\
\hline Poland & Jan-95 & Independent & 0.0000 & 0.0078 & 0.0004 & 0.0219 & 0.117 & 0.88 \\
\hline Russia & Mar-96 & Managed & 0.0005 & 0.0186 & 0.0003 & 0.0312 & 0.215 & 1.76 \\
\hline Singapore & Dec-93 & Managed & -0.0001 & 0.0036 & -0.0001 & 0.0157 & 1.562 & 0.47 \\
\hline South Africa & Dec-93 & Independent & 0.0002 & 0.0096 & 0.0002 & 0.0152 & 1.528 & 0.53 \\
\hline Korea & Dec-93 & Independent & 0.0001 & 0.0094 & 0.0000 & 0.0217 & 0.009 & 0.76 \\
\hline Taiwan & Dec-93 & Managed & 0.0000 & 0.0028 & -0.0001 & 0.0201 & 1.015 & 0.18 \\
\hline Thailand & Dec-93 & Managed & 0.0000 & 0.0060 & -0.0001 & 0.0213 & 0.556 & 0.82 \\
\hline Turkey & Dec-93 & Independent & 0.0010 & 0.0140 & 0.0012 & 0.0282 & 0.260 & 1.76 \\
\hline
\end{tabular}

Notes: Dates indicate the starting date for the data in our sample. Currency regime is the exchange rate system, based on Bekaert and Hodrick (2009). Independent refers to independent floating. Managed refers to managed floating. FXR is the daily exchange rate return calculated as the $\log$ difference of the spot exchange rates, which are in foreign currency units per U.S. dollar. MSCI_Excess is the excess emerging stock market return calculated as the difference between the emerging market and US market MSCI returns. MCap/GDP is the ratio of the country's stock market capitalization to GDP. Crisis is the average index of the country's crisis index, based on Reinhart (2010). Crisis data for the Czech Republic and Hong Kong are unavailable.

\section{Empirical Findings}

\subsection{Correlations between Exchange Rates and Excess Equity Market Returns in Emerging Economies}

Table 2 presents the daily and monthly correlations of exchange rate returns and excess emerging stock market returns. Of the 23 countries analyzed, the daily correlation is positive for 20 countries, with 16 countries significant at 1\% level and Czech Republic and Morocco significant at 5\% and 10\% levels, respectively. Chile, China and Egypt have negative daily correlations, which is significant for Egypt at 10\% level. For monthly data, we find that 15 countries show positive correlations, and 11 countries have positive and significant correlations. Notably, none of the countries in our sample has a significantly negative correlation as predicted by Hau and Rey (2006). These findings are supported at regional levels with significant and positive daily correlations for eight countries in Asia, four countries in Latin America and seven countries in emerging Europe and Africa. Based on the results for the total sample, we find strong statistical evidence that the portfolio rebalancing model does not hold for emerging economies. 
Table 2. Correlations of Exchange Rate Returns and Excess Emerging Stock Market Returns

\begin{tabular}{|c|c|c|c|c|c|c|}
\hline & All Sample & & 1994-2002 & & 2003-2010 & \\
\hline Country & Daily & Monthly & Daily & Monthly & Daily & Monthly \\
\hline \multicolumn{7}{|l|}{$\begin{array}{l}\text { Higher market } \\
\text { capitalization }\end{array}$} \\
\hline Brazil & $0.1040 * * *$ & -0.0076 & 0.0193 & -0.0880 & $0.2248 * * *$ & 0.1011 \\
\hline Chile & -0.0233 & -0.0795 & -0.0136 & 0.1133 & $-0.0966^{* * *}$ & -0.1980 \\
\hline Hong Kong & 0.0101 & 0.0469 & -0.0152 & $0.2060 * *$ & 0.0381 & 0.0480 \\
\hline India & $0.1473^{* * *}$ & $0.2481 * * *$ & 0.0235 & $0.1797 *$ & $0.2418^{* * *}$ & $0.2327 * *$ \\
\hline Malaysia & $0.1060^{* * *}$ & $0.1479 * *$ & $0.1159^{* * *}$ & $0.1885^{*}$ & $0.0532 * *$ & $-0.3291 * * *$ \\
\hline Mexico & $0.0605 * * *$ & $0.1550^{* *}$ & $0.0531 * *$ & $0.2209^{* *}$ & $0.0586^{* *}$ & -0.1234 \\
\hline Philippines & $0.1158 * * *$ & $0.2008 * * *$ & $0.1089 * * *$ & $0.2559 * * *$ & $0.1426^{* * *}$ & -0.1340 \\
\hline Singapore & $0.1016^{* * *}$ & $0.1802 * * *$ & $0.1305^{* * *}$ & $0.2804 * * *$ & $0.0418^{*}$ & -0.1230 \\
\hline South Africa & 0.0137 & -0.0829 & -0.0079 & 0.1508 & $-0.0514^{* *}$ & $-0.2451 * *$ \\
\hline Taiwan & $0.1864 * * *$ & $0.1914 * * *$ & $0.1885^{* * *}$ & $0.2150 * *$ & $0.1790 * * *$ & 0.0879 \\
\hline Thailand & $0.1448 * * *$ & 0.0295 & $0.1678 * * *$ & -0.037 & $0.0942 * * *$ & $0.2110^{* *}$ \\
\hline \multicolumn{7}{|l|}{$\begin{array}{l}\text { Lower market } \\
\text { capitalization }\end{array}$} \\
\hline China & -0.0181 & $0.1355^{*}$ & -0.0277 & 0.1467 & $0.0858 * * *$ & 0.1594 \\
\hline Colombia & $0.0505^{* * *}$ & -0.0024 & 0.0119 & -0.0558 & $0.0713 * * *$ & -0.0748 \\
\hline Czech & $0.0360 * *$ & -0.0040 & 0.0183 & 0.0734 & -0.0270 & $-0.2139^{*}$ \\
\hline Egypt & $-0.0265^{*}$ & -0.1195 & 0.0336 & -0.1139 & $-0.0490 * *$ & -0.1754 \\
\hline Hungary & $0.1181^{* * *}$ & 0.0617 & 0.0043 & -0.0496 & $0.1562 * * *$ & 0.0691 \\
\hline Indonesia & $0.1859 * * *$ & -0.0144 & $0.1885^{* * *}$ & -0.0818 & $0.3087 * * *$ & $0.2783^{* *}$ \\
\hline Morocco & $0.0294 *$ & -0.1173 & $0.1243 * * *$ & 0.1470 & $-0.0868 * * *$ & -0.3175 \\
\hline Peru & $0.0473^{* * *}$ & $0.1797 * * *$ & 0.0273 & $0.2311 * *$ & $0.0750 * * *$ & 0.1674 \\
\hline Poland & $0.1179 * * *$ & $0.1315^{*}$ & $0.0668 * * *$ & $0.2068 * *$ & $0.1543 * * *$ & 0.0473 \\
\hline Russia & $0.1696^{* * *}$ & $0.4676^{* * *}$ & $0.1775^{* * *}$ & $0.5004 * * *$ & $0.2274 * * *$ & $0.2692 * *$ \\
\hline South Korea & $0.2466^{* * *}$ & 0.1062 & $0.2312 * * *$ & $0.1998^{* *}$ & $0.2234 * * *$ & -0.1739 \\
\hline Turkey & $0.1237 * * *$ & $0.1581 * *$ & $0.0538^{* * *}$ & 0.1510 & $0.4141 * * *$ & $0.3525 * * *$ \\
\hline
\end{tabular}

Notes: This table reports the Pearson correlations of exchange rate returns on excess emerging stock market returns relative to the U.S. stock market returns. The subsample 2003-2010 excludes the data for $2008 . * * *$, and $* * *$ denote significance at $10 \%, 5 \%$, and $1 \%$ levels, respectively.

\subsection{Financial Market Development and Integration}

To investigate whether the correlations change over time, we divide the sample into two sub-periods, 1994-2002 and 2003-2010. The period 1994-2002 marks the beginning of market openness for emerging economies. This period experiences a large number of financial crises, leading to credit freezes, stock market reforms and capital controls (Bekaert \& Harvey, 2003). The period 2003-2010, from which we exclude 2008, is characterized by financial market openness and integration with the financial systems around the world functioning smoothly, except for 2008. Moreover, technological progress leads the integration, allowing better access to emerging stock markets and currency trading. Table 2 reports the results. At the daily level, 12 countries show significant correlations for 1994-2002, while 21 countries exhibit significant correlations for 2003-2010. We note that nine countries, including Brazil, Chile, China, Colombia, Egypt, Hungary, India, Peru and South Africa, have insignificant daily correlations during 1994-2002 and highly significant correlations during 2003-2010 when the degree of financial market integration is higher. The monthly correlations reveal fewer significant changes for the two sub-periods, with 11 countries showing significant correlations during 1994-2002 and eight countries showing significant correlations during 2003-2010. Analyzing separately the countries with higher (lower) market capitalizations indicates that the number of countries with significant correlations is similar for the two subsamples. Across geographical regions, ten countries have shown insignificant daily correlations for 1994-2002 and significant correlations for 2003-2010, including two countries in Asia (China and India), four countries in Latin America (Brazil, Chile, Colombia and Peru), and four countries in emerging Europe and Africa (the Czech Republic, Egypt, Hungary and South Africa). Overall, the results are consistent with Hau and Rey (2006) indicating that financial market development and integration affect the correlation between exchange rates and equity market returns. 


\subsection{Currency Regimes, Capital Controls and Financial Crises}

Table 3 reports the country regressions of exchange rate returns on excess emerging stock market returns, tabulated by alternative exchange rate systems. The results show that, for countries with a pegged exchange rate system, including China, Egypt, Hong Kong and Morocco, the estimated coefficients are insignificant supporting the prediction of Hau and Rey (2006) that the portfolio rebalancing model may not hold for pegged exchange rate systems. For countries with declared independent floating and managed floating systems, the estimated coefficients are positive and significant for 16 of the 18 countries based on daily data, and positive and significant for eight countries ( 13 countries positive) based on monthly data. These results do not support the portfolio rebalancing model of Hau and Rey (2006). None of the countries in our sample exhibits a significantly negative coefficient. Among the countries with a declared independent floating system, Chile is the only country with a negative coefficient.

Several countries in our sample impose controls on foreign capital inflows and outflows during various periods of this study, including Brazil, Chile, China, Colombia, the Czech Republic, India, Indonesia, Korea, Malaysia, Peru and Thailand (Note 4). Controls on capital outflows in Malaysia, Thailand and South Africa have been gradually relaxed in our sample period. Across geographical regions, many Asian countries impose strict rules for capital controls while Latin American countries introduce capital controls periodically during our sample period. Table 3 indicates that the estimated coefficients for countries with capital controls are predominantly positive and significant based on daily data, except for Chile and China. Based on monthly data, the estimated coefficients are generally insignificant for countries with capital controls. Overall, these results are consistent with the literature that controlling capital flows are less successful in easing the upward pressure on exchange rates (Baba \& Kokenyne, 2011, Magud et al., 2011), indicating that capital controls have a limited impact on the correlation between the exchange rate returns and excess emerging stock market returns regardless of geographical locations.

To test whether financial crises affect the correlation between exchange rate returns and excess emerging stock market returns, we obtain a subsample of daily observations from which we eliminate all the years when a country confronted with a crisis. Crisis data for the Czech Republic and Hong Kong are unavailable. The last two columns of Table 3 report the results. We find that 19 of the 21 countries analyzed show positive relationship between exchange rate returns and excess emerging stock market returns, and 17 countries with significantly positive regression coefficients. The results are similar across regions of Asia, Latin America, emerging Europe and Africa.

Overall, Tables 3 confirms the evidence reported in Table 2 that the portfolio rebalancing model does not hold for our sample of emerging economies. Our results are robust to alternative exchange rate systems, capital controls, and financial crises. 
Table 3. Regressions of Exchange Rate Returns on Excess Emerging Stock Market Returns

\begin{tabular}{|c|c|c|c|c|c|c|}
\hline \multicolumn{7}{|c|}{ Independent Floating } \\
\hline & Daily & (t-stat) $\mathrm{N}$ & Monthly & (t-stat) $\mathrm{N}$ & Non-Crisis & (t-stat) $\mathrm{N}$ \\
\hline Brazil & $0.0582 * *$ & (2.35) 4265 & -0.0059 & $(-0.05) 196$ & $0.1634 * * *$ & (8.74) 1785 \\
\hline Chile & -0.0108 & $(-0.93) 4394$ & -0.0424 & $(-0.91) 202$ & $-0.0358 * * *$ & $(-3.57) 3088$ \\
\hline Mexico & $0.0457 *$ & (1.71) 4394 & 0.1145 & (1.53) 202 & $0.0262 *$ & (1.67) 2046 \\
\hline Philippines & $0.0356 * * *$ & (3.54) 4394 & $0.0710^{* * *}$ & (2.65) 202 & $0.0256^{* * *}$ & (4.96) 2047 \\
\hline Poland & $0.0472 * * *$ & (5.48) 4132 & $0.0625^{*}$ & (1.73) 189 & $0.0893 * * *$ & (5.04) 1785 \\
\hline South Africa & 0.0085 & (0.54) 4394 & -0.0685 & $(-0.92) 202$ & 0.0085 & (0.54) 4394 \\
\hline South Korea & $0.1038 * * *$ & (7.02) 4394 & 0.0588 & (1.00) 202 & $0.0731^{* * *}$ & (7.24) 2045 \\
\hline Turkey & $0.0615^{* * *}$ & (3.66) 4394 & $0.0729 * *$ & $(2.18) 202$ & $0.1596^{* * *}$ & $(10.68) 1524$ \\
\hline \multicolumn{7}{|c|}{ Managed Floating } \\
\hline & Daily & (t-stat) $\mathrm{N}$ & Monthly & (t-stat) $\mathrm{N}$ & Non-Crisis & (t-stat) $\mathrm{N}$ \\
\hline Colombia & $0.0185^{* *}$ & (2.49) 4394 & -0.0009 & $(-0.03) 202$ & $0.0241 * *$ & (2.45) 1785 \\
\hline Czech & 0.0154 & (1.40) 4134 & -0.0021 & $(-0.05) 190$ & $\mathrm{n} / \mathrm{a}$ & $\mathrm{n} / \mathrm{a}$ \\
\hline Hungary & $0.0462 * * *$ & (5.09) 4134 & 0.0288 & $(0.72) 190$ & $0.0217 * *$ & (2.34) 1565 \\
\hline India & $0.0251 * * *$ & (6.78) 4394 & $0.0570 * * *$ & (3.33) 202 & $0.0363 * * *$ & (5.63) 2307 \\
\hline Indonesia & $0.1251 * * *$ & (4.83) 4394 & -0.0118 & $(-0.09) 202$ & $0.0900 * * *$ & (8.07) 1525 \\
\hline Malaysia & $0.0435 * * *$ & (3.67) 4394 & 0.0675 & (1.49) 202 & 0.0083 & (1.48) 2308 \\
\hline Peru & $0.0081 * *$ & (2.20) 4394 & $0.0310^{* *}$ & (2.03) 202 & $0.0059 *$ & (1.72) 2046 \\
\hline Russia & $0.1004 * * *$ & (2.59) 3826 & $0.1911^{*}$ & (1.78) 175 & $0.0218 * * *$ & (5.96) 1785 \\
\hline Singapore & $0.0218 * * *$ & (4.25) 4394 & $0.0584 * *$ & (2.29) 202 & $0.0119^{* *}$ & (2.29) 2566 \\
\hline Taiwan & $0.0268 * * *$ & (7.69) 4394 & $0.0441^{* *}$ & (2.31) 202 & $0.0268 * * *$ & (7.69) 4394 \\
\hline Thailand & $0.0395 * * *$ & (3.53) 4394 & 0.0094 & $(0.22) 202$ & $0.0222 * * *$ & (5.30) 2308 \\
\hline \multicolumn{7}{|c|}{ Pegged system } \\
\hline & Daily & (t-stat) $\mathrm{N}$ & Monthly & (t-stat) $\mathrm{N}$ & Non-Crisis & (t-stat) $\mathrm{N}$ \\
\hline China & -0.0049 & (0.86) 4394 & 0.0435 & (1.03) 202 & $0.0017 * * *$ & (2.82) 1262 \\
\hline Egypt & -0.0047 & $(-0.79) 4134$ & -0.0220 & $(-0.63) 190$ & -0.0047 & $(-0.79) 4134$ \\
\hline Hong Kong & 0.0001 & (0.47) 4394 & 0.0009 & (0.90) 202 & $\mathrm{n} / \mathrm{a}$ & $\mathrm{n} / \mathrm{a}$ \\
\hline Morocco & 0.0098 & (1.43) 4134 & -0.0403 & $(-1.45) 190$ & 0.0098 & (1.43) 4134 \\
\hline
\end{tabular}

Notes: This table reports the regression coefficients for exchange rate returns on excess emerging stock market returns relative to US stock market returns. The data are for daily and monthly frequency. The subsample Non-Crisis contains daily observations excluding all the years when a country confronted with a crisis, based on Reinhart (2010). Crisis data for the Czech Republic and Hong Kong are unavailable. The exchange rate system is based on Bekaert and Hodrick (2009). The t-statistics are in parentheses. $\mathrm{N}$ is the number of observations. *, **, and *** denote significance at $10 \%, 5 \%$, and $1 \%$ levels, respectively.

\subsection{Cross-market Correlations}

To test whether cross-market correlations affect our results, we re-estimate Equation 1 using the SUR system. The data starts from March 1996, the starting date for Russia in our sample. The number of observations is 3090 at daily frequency for each country in the regression system. Our SUR system consists of 32 countries including 23 emerging economies and nine developed economies of Australia, Canada, Denmark, the euro zone, Japan, Norway, Sweden, Switzerland, and the United Kingdom (Note 5). The explanatory variable is the excess foreign stock market return, calculated for each country, as the difference between the foreign market and US market MSCI returns. The SUR estimators gain efficiency by jointly estimating 32 equations in the system and correcting for the correlations of the error terms across 32 countries. Table 5 reports the results. The estimated coefficients for the Euro zone, Japan, Switzerland and UK are negative and significant at $1 \%$ level, confirming that the portfolio rebalancing model holds for developed economies (Hau \& Rey, 2006). The estimated coefficients for Australia and Canada are positive and significant at $1 \%$ level, confirming that the portfolio rebalancing model does not hold for commodity currencies (Chaban, 2009). The estimated coefficients are positive and significant for 18 of the 23 emerging economies, with 15 countries significant at $1 \%$ level and two countries significant at 5\% and 10\% levels, respectively. Chile and Egypt show negative coefficients with 10\% level of significance. Across geographical regions, the estimated coefficients are positive for nine emerging economies in Asia, four in Latin America and five in emerging Europe. Overall, Table 4 confirms that the portfolio rebalancing model does not hold for our sample of emerging economies. 
Table 4. SUR of Exchange Rate Returns on Excess Foreign Stock Market Returns

\begin{tabular}{|c|c|c|c|c|c|c|}
\hline Developed Countries & Coefficient & $\mathrm{SE}$ & $\mathrm{z}$ & $\mathrm{P}>|\mathrm{z}|$ & $\chi^{2}$ & Adj. $R^{2}$ \\
\hline Australia & $0.1075^{* * *}$ & 0.009861 & 10.91 & 0 & $119.01 * * *$ & 0.0688 \\
\hline Canada & $0.0247 * * *$ & 0.006480 & 3.82 & 0 & $14.58^{* * *}$ & 0.0199 \\
\hline Denmark & $0.0027^{* * *}$ & 0.000917 & 3.01 & 0.003 & $9.06^{* * *}$ & 0.0005 \\
\hline Euro & $-0.0103 * * *$ & 0.000796 & -13.00 & 0 & $168.97 * * *$ & 0.0007 \\
\hline Japan & $-0.0328 * * *$ & 0.007113 & -4.61 & 0 & $21.27 * * *$ & 0.0143 \\
\hline Norway & $0.0525^{* * *}$ & 0.004406 & 11.93 & 0 & $142.33^{* * *}$ & 0.0455 \\
\hline Sweden & $0.0574 * * *$ & 0.003721 & 15.45 & 0 & $238.55^{* * *}$ & 0.0346 \\
\hline Switzerland & $-0.0778 * * *$ & 0.004021 & -19.36 & 0 & $374.86^{* * *}$ & 0.0374 \\
\hline UK & $-0.0187 * * *$ & 0.005970 & -3.15 & 0.002 & $9.91 * * *$ & -0.0077 \\
\hline EM-Asia & Coefficient & SE & $\mathrm{z}$ & $\mathrm{P}>|\mathrm{z}|$ & $\chi^{2}$ & Adj. $R^{2}$ \\
\hline China & 0.0003 & 0.000540 & 0.59 & 0.556 & 0.35 & 0.0005 \\
\hline Hong Kong & -0.0001 & 0.000286 & -0.13 & 0.895 & 0.02 & -0.0001 \\
\hline India & $0.0282 * * *$ & 0.002417 & 11.7 & 0 & $136.93 * * *$ & 0.0373 \\
\hline Indonesia & $0.0816^{* * *}$ & 0.006372 & 12.82 & 0 & $164.28 * * *$ & 0.0507 \\
\hline Malaysia & $0.0175^{* * *}$ & 0.004470 & 3.92 & 0 & $15.34 * * *$ & -0.0004 \\
\hline Philippines & $0.0383^{* * *}$ & 0.003607 & 10.63 & 0 & $112.94 * * *$ & 0.0182 \\
\hline Singapore & $0.0043 * *$ & 0.002228 & 1.97 & 0.049 & $3.88 * *$ & 0.0024 \\
\hline South Korea & $0.0702 * * *$ & 0.004758 & 14.77 & 0 & $218.21 * * *$ & 0.0566 \\
\hline Taiwan & $0.0226^{* * *}$ & 0.001958 & 11.57 & 0 & $133.79 * * *$ & 0.0345 \\
\hline Thailand & $0.0160 * * *$ & 0.003132 & 5.14 & 0 & $26.39 * * *$ & 0.0118 \\
\hline EM-Latin America & Coefficient & $\mathrm{SE}$ & $\mathrm{z}$ & $P>|z|$ & $\chi^{2}$ & Adj. $R^{2}$ \\
\hline Brazil & 0.0162 & 0.011149 & 1.46 & 0.145 & 2.13 & 0.0049 \\
\hline Chile & $-0.0133^{*}$ & 0.007718 & -1.73 & 0.084 & $2.99 *$ & 0.0012 \\
\hline Colombia & $0.0279 * * *$ & 0.006154 & 4.54 & 0 & $20.6^{* * *}$ & 0.0032 \\
\hline Mexico & $0.0125^{* *}$ & 0.007350 & 1.71 & 0.087 & $2.93 *$ & 0.0037 \\
\hline Peru & 0.0018 & 0.002784 & 0.68 & 0.498 & 0.46 & 0.0011 \\
\hline EM-EMEA & Coefficient & SE & $\mathrm{z}$ & $\mathrm{P}>|\mathrm{z}|$ & $\chi^{2}$ & Adj. $R^{2}$ \\
\hline Czech & -0.0057 & 0.003563 & -1.61 & 0.107 & 2.59 & -0.0012 \\
\hline Egypt & $-0.0064^{*}$ & 0.003348 & -1.94 & 0.053 & $3.75^{*}$ & 0.001 \\
\hline Hungary & $0.0189 * * *$ & 0.004071 & 4.66 & 0 & $21.74 * * *$ & 0.0106 \\
\hline Morocco & $0.0031 *$ & 0.001778 & 1.77 & 0.077 & $3.13 *$ & 0.0002 \\
\hline Poland & $0.0199 * * *$ & 0.004860 & 4.11 & 0 & $16.90 * * *$ & 0.0087 \\
\hline Russia & $0.0221^{* * *}$ & 0.003089 & 7.18 & 0 & $51.59 * * *$ & 0.0298 \\
\hline South Africa & $-0.0430 * * *$ & 0.009512 & -4.53 & 0 & $20.48 * * *$ & -0.0025 \\
\hline Turkey & $0.0573 * * *$ & 0.008279 & 6.92 & 0 & $47.91 * * *$ & 0.0253 \\
\hline
\end{tabular}

Notes: This table reports the results for the seemingly unrelated regression (SUR) systems of daily exchange rate returns on daily excess foreign stock market returns relative to US stock market returns. *, **, and *** denote significance at $10 \%, 5 \%$, and $1 \%$ levels, respectively.

\subsection{Equity Flows and Exchange Rates}

Table 5 reports the correlations of monthly exchange rate returns and net increase in foreign stock ownership by US residents (or net foreign equity inflows). The net foreign equity inflows are calculated as net US purchases of foreign equities minus net purchases of US equities by foreigners, normalized as a proportion of the average absolute level of increase in net foreign stock ownership by US residents over the previous 12 months. For the overall sample, eight countries have negative correlations and 15 countries have positive correlations, suggesting that higher equity flows are associated with stronger currencies. The sub-period results indicate that 13 countries have positive correlations for 1994-2002 and 18 countries have positive correlations for 2003-2010. Overall, the evidence supports the prediction of Hau and Rey (2006) that equity flows are positively correlated with exchange rates and is consistent with the literature on capital flows to emerging economies. 
Table 5. Correlations of Exchange Rate Returns and Net Foreign Equity Inflows

\begin{tabular}{|c|c|c|c|}
\hline Country & All Sample & 1994-2002 & 2003-2010 \\
\hline Brazil & 0.0683 & 0.0436 & 0.1240 \\
\hline Chile & 0.0356 & -0.0963 & 0.1050 \\
\hline China & -0.0143 & -0.0061 & -0.1362 \\
\hline Colombia & 0.0096 & -0.0283 & 0.0791 \\
\hline Czech & -0.1062 & -0.1942 & 0.0668 \\
\hline Egypt & 0.0025 & -0.0054 & 0.0056 \\
\hline Hong Kong & 0.0931 & 0.0275 & 0.1396 \\
\hline Hungary & 0.0156 & 0.0228 & 0.0443 \\
\hline India & 0.0924 & 0.0895 & 0.2048 \\
\hline Indonesia & -0.0099 & -0.0254 & 0.0853 \\
\hline Malaysia & 0.0703 & 0.0657 & 0.1098 \\
\hline Mexico & -0.0605 & -0.0193 & -0.1277 \\
\hline Morocco & -0.0584 & -0.0600 & -0.0708 \\
\hline Peru & -0.0551 & 0.0012 & -0.2881 \\
\hline Philippines & 0.0489 & 0.0369 & 0.0777 \\
\hline Poland & 0.0066 & 0.0141 & 0.0034 \\
\hline Russia & -0.0032 & 0.0181 & -0.0470 \\
\hline Singapore & -0.0367 & -0.1464 & 0.1474 \\
\hline South Africa & 0.1082 & 0.0545 & 0.2078 \\
\hline South Korea & 0.0579 & 0.0356 & 0.1798 \\
\hline Taiwan & 0.0558 & 0.0507 & 0.0702 \\
\hline Thailand & 0.1014 & 0.1030 & 0.0978 \\
\hline Turkey & 0.0180 & -0.0288 & 0.1187 \\
\hline
\end{tabular}

Notes: This table reports the Pearson correlations of monthly exchange rate returns and net US purchases of foreign equities minus net purchases of US equities by foreigners, normalized as a proportion of the average absolute level of increase in net foreign stock ownership by US residents over the previous 12 months.

\section{Conclusion}

This paper tests the portfolio rebalancing model of Hau and Rey (2006) for a sample of 23 emerging economies at different stages of capital market development and from diverse geographical regions. We find significant and positive correlations between the exchange rate returns and excess emerging stock market returns relative to the United States, indicating that positive shocks in emerging equity markets are associated with appreciation of the emerging market currencies. This result suggests that the portfolio-rebalancing perspective of foreign exchange markets does not hold for our sample of emerging economies. Our findings take into account cross-market correlations and are robust to emerging economies with different stock market capitalizations, alternative exchange rate systems, capital controls and financial crises. We also find that, consistent with previous research, higher equity flows are associated with stronger currencies for our sample of emerging economies.

\section{Acknowledgements}

We thank the participants at 2011 Financial Management Association meetings for helpful comments. All remaining errors are the authors' responsibilities.

\section{References}

Ang, A., \& Bekaert, G. (2002). International asset allocation with regime shifts. Review of Financial Studies, 15, 1137-1187. http://dx.doi.org/10.1093/rfs/15.4.1137

Baba, C., \& Kokenyne, A. (2011). Effectiveness of capital controls in selected emerging markets in the 2000s, IMF Working Paper 11/281. http://www.imf.org/external/pubs/ft/wp/2011/wp11281.pdf

Bae, K. H., Karolyi, G. A., \& Stulz, R. M. (2003). A new approach to measuring financial contagion. Review of Financial Studies, 16, 717-763. http://dx.doi.org/10.1093/rfs/hhg012

Bailey, W., Chan, K., \& Chung, Y. P. (2000). Depository receipts, country funds, and the peso crash: the intraday evidence. Journal of Finance, 55, 2693-2717. http://dx.doi.org/10.1111/0022-1082.00303

Bank for International Settlements. (2010). Triennial central bank survey: report on global foreign exchange 
market activity in 2010, Basel, Switzerland. http://www.bis.org/publ/rpfxf10t.pdf

Bekaert, G., \& Harvey, C. R. (1995). Time-varying world market integration. Journal of Finance, 50, 403-444. http://dx.doi.org/10.1111/j.1540-6261.1995.tb04790.x

Bekaert, G., \& Harvey, C. R. (1997). Emerging equity market volatility. Journal of Financial Economics, 43, 29-78. http://dx.doi.org/10.1016/S0304-405X(96)00889-6

Bekaert, G., \& Harvey, C. R. (2000). Foreign speculators and emerging equity markets. Journal of Finance, 55, 565-614. http://dx.doi.org/10.1111/0022-1082.00220

Bekaert, G., \& Harvey, C. R. (2003). Emerging markets finance. Journal of Empirical Finance, 10, 3-55. http://dx.doi.org/10.1016/S0927-5398(02)00054-3

Bekaert, G., Harvey, C. R., \& Lundblad, C. R. (2005). Does financial liberalization spur growth? Journal of Financial Economics, 77, 3-55. http://dx.doi.org/10.1016/j.jfineco.2004.05.007

Bekaert, G., Harvey, C. R., \& Ng, A. (2005). Market integration and contagion. Journal of Business, 78, 32-69. http://dx.doi.org/10.1086/426519

Bekaert, G., \& Hodrick, R. J. (2009). International Financial Management. Pearson/Prentice Hall, Upper Saddle River, New Jersey.

Binici, M., Hutchison, M., \& Schindler, M. (2009). Controlling capital legal restrictions the asset composition of international financial flows, IMF Working Paper 09/208. http://www.imf.org/external/pubs/ft/wp/2009/ wp09208.pdf

Bohn, H., \& Tesar, L. (1996). US equity investment in foreign markets: portfolio rebalancing or return chasing? American Economic Review, 86, 77-81.

Brennan, M. J., \& Cao, H. H. (1997). International portfolio flows. Journal of Finance, 52, 1851-1880. http://dx.doi.org/10.1111/j.1540-6261.1997.tb02744.x

Brooks, R., Edison, H., Kumar, M. S., \& Slok, T. (2004). Exchange rates and capital flows. European Financial Management, 10, 511-533. http://dx.doi.org/10.1111/j.1354-7798.2004.00261.x

Calvo, S., \& Reinhart, C. M. (1996). Capital flows to Latin America: is there evidence of contagion effects? In Private Capital Flows to Emerging Markets, Morris Goldstein (Eds), Institute for International Economics, Washington DC.

Calvo, S., \& Reinhart, C. M. (2002). Fear of floating. Quarterly Journal of Economics, 117, 379-408. http://dx.doi.org/10.1162/003355302753650274

Campbell, J. Y., Serfaty-de Medeiros, K., \& Viceira, L. M. (2010). Global currency hedging. Journal of Finance 65, 87-121. http://dx.doi.org/10.1111/j.1540-6261.2009.01524.x

Carrieri, F., Errunza, V., \& Hogan, K. (2007). Characterizing world market integration through time. Journal of Financial and Quantitative Analysis, 42, 915-940. http://dx.doi.org/10.1017/S0022109000003446

Chaban, M. (2009). Commodity currencies and equity flows. Journal of International Money and Finance, 28 , 836-852. http://dx.doi.org/10.1016/j.jimonfin.2008.08.004

Choe, H., Kho, B. C., \& Stulz, R. (1999). Do foreign investors destabilize stock markets? the Korean experience in 1997. Journal of Financial Economics, 54, 227-264. http://dx.doi.org/10.1016/S0304-405X(99)00037-9

Concha, A., \& Galindo, A. J. (2011). An assessment of another decade of capital controls in Columbia: 1998-2008. Quarterly Review of Economics and Finance, 51, 319-338. http://dx.doi.org/10.1016/j.qref.2011.08.002

Edelen, R. M., \& Warner, J. B. (2001). Aggregate price effects of institutional trading: a study of mutual fund flow and market returns. Journal of Financial Economics, 59, 195-220. http://dx.doi.org/10.1016/S0304-405X(00)00085-4

Edwards, S. (2007). Capital controls and capital flows in emerging economies: policies, practices, and consequences, National Bureau of Economic Research and The University of Chicago Press, Cambridge, Massachusetts.

Edwards, S., \& Rigobon, R. (2009). Capital controls on inflows, exchange rate volatility and external $\begin{array}{llllll}\text { vulnerability. Journal of International Economics, } & 78, & \text { 256-267. }\end{array}$ http://dx.doi.org/10.1016/j.jinteco.2009.04.005 
Forbes, K. J. (2004). The Asian flu and Russian virus: the international transmission of crises in firm-level data. Journal of International Economics, 63, 59-93. http://dx.doi.org/10.1016/S0022-1996(03)00044-8

Forbes, K. J., \& Rigobon. R. (2002). No contagion, only interdependence: measuring stock market co-movements. Journal of Finance, 55, 2223-2261. http://dx.doi.org/10.1111/0022-1082.00494

Frankel, J., \& Poonawala, J. (2010). The forward market in emerging currencies: less biased than major currencies. Journal of International Money and Finance, 29, 585-598. http://dx.doi.org/10.1016/j.jimonfin.2009.11.004

Froot, K., \& Ramadorai, T. (2008). Institutional portfolio flows and international investments. Review of Financial Studies, 21, 937-971. http://dx.doi.org/10.1093/rfs/hhm091

Froot, K. A., O'Connell, P. G. I., \& Seasholes, M. S. (2001). The portfolio flows of international investors. Journal of Financial Economics, 59, 151-193. http://dx.doi.org/10.1016/S0304-405X(00)00084-2

Griffin, J. M., Nardari, F., \& Stulz, R. M. (2004). Are daily cross-border equity flows pushed or pulled? Review of Economics and Statistics, 86, 641-657. http://dx.doi.org/10.1162/0034653041811725

Griffin, J. M., Nardari, F., \& Stulz, R. M. (2007). Do investors trade more when stocks have performed well? evidence from 46 countries. Review of Financial Studies, 20, 905-951. http://dx.doi.org/10.1093/rfs/hhl019

Hau, H., \& Rey, H. (2006). Exchange rates, equity prices, and capital flows. Review of Financial Studies, 19, 273-317. http://dx.doi.org/10.1093/rfs/hhj008

Henry, P. B. (2000). Stock market liberalization, economic reform and emerging market equity prices. Journal of Finance, 55, 529-564. http://dx.doi.org/10.1111/0022-1082.00219

International Monetary Fund. (2011a). Tensions from the two-speed recovery: unemployment, commodities, and capital flows, World Economic Outlook (WEO). Retrieved from http://www.imf.org/external/pubs/ft/weo/2011/01/

International Monetary Fund. (2011b). Recent experiences in managing capital inflows - cross-cutting themes and possible policy framework, Strategy, Policy and Review Department. Retrieved from http://www.imf.org/external/np/pp/eng/2011/ 021411a.pdf

Kaminsky, G., Lyons, R. K., \& Schmukler, S. L. (2004). Managers, investors, and crises: mutual fund strategies in emerging markets. Journal of International Economics, 64, 113-134. http://dx.doi.org/10.1016/S0022-1996(03)00075-8

Kim, W., \& Wei, S. J. (2002). Foreign portfolio investors before and during a crisis. Journal of International Economic, 56, 77-96. http://dx.doi.org/10.1016/S0022-1996(01)00109-X

Lipscomb, L. (2005). An overview of non-deliverable foreign exchange forward markets, Federal Reserve Bank of New York, New York. Retrieved from http://www.bis.org/publ/cgfs22fedny5.pdf

Longin, F., \& Solnik, B. (2001). Extreme correlation of international equity markets. Journal of Finance, 56, 649-676. http://dx.doi.org/10.1111/0022-1082.00340

Magud, N. E., Reinhart, C. M., \& Rogoff, K. S. (2011). Capital controls: myth and reality - a portfolio balance approach, Peterson Institute for International Economics Working Paper Series. Retrieved from http://www.imf.org/ external/np/pp/eng/2011/021411a.pdf

Newey, W., \& West, K. (1987). A simple, positive semi-definite heteroskedasticity and autocorrelation consistent covariance matrix. Econometrica, 55, 703-708. http://dx.doi.org/10.2307/1913610

Ostry, J., Ghosh, A. R., Habermerier, K., Chamon, M., Qureshi, M., \& Reinhart, D. B. S. (2010). Capital inflows: the role of controls, IMF Staff Position Note 10/04. Retrieved from http://www.imf.org/external/pubs/ft/spn/2010/spn1004.pdf

Reinhart, C. M. (2010). This time is different chartbook: country histories on debt, default, and financial crises, NBER Working Paper No.15815. Retrieved from http://www.nber.org/papers/w15815

Remsperger, H. (2007). Developing bond markets in emerging market economies: conclusions and political recommendations. Speech delivered at the workshop Developing Bond Markets in Emerging Market Economies, Deutsche Bundesbank (Eurosystem), Frankfurt. Retrieved from http://www.bis.org/review/ r070514f.pdf

Richards, A. J. (2005). Big fish in small ponds: the momentum investing and price impact of foreign investors in Asian emerging equity markets. Journal of Financial and Quantitative Analysis, 40, 1-27. 
http://dx.doi.org/10.1017/S0022109000001721

Rincon, H., \& Toro, J. (2010). Are capital controls and central bank intervention effective? Borradores de Economia No. 625, Central Bank of Columbia. Retrieved from http://ideas.repec.org/p/col/000094/007622.html

Saxena, S., \& Villar, A. (2008). Hedging instruments in emerging market economies. Financial Globalisation and Emerging Market Capital Flows, 44, 71-87.

Siourounis, G. (2004). Capital flows and exchange rates: an empirical analysis, mimeo, London Business School. Retrieved from http://papers.ssrn.com/sol3/papers.cfm?abstract_id $=572025$

Swanson, P. E. \& Lin, A. Y. (2003). The role of U.S. investors in international equity market inflows, outflows, and net flows for selected emerging Asian markets. Journal of Economics and Finance, 27, 300-320. http://dx.doi.org/10.1007/BF02761568

Tesar, L., \& Werner, I. (1994). International equity transactions and US portfolio choice, In Internationalization of Equity Markets, (Eds) J. Frankel, NBER Project Report, University of Chicago Press, Chicago, 185-216.

Tesar, L., \& Werner, I. (1995). US equity investment in emerging stock markets. World Bank Economic Review, 9, 109-129. http://dx.doi.org/10.1093/wber/9.1.109

\section{Notes}

Note 1. For instance, in the period 2006-2007, the California Public Employees' Retirement System had about $90 \%$ of the increased exposure to foreign securities in emerging market currencies.

Note 2. See Edwards (2007) \& Magud et al. (2011) for extensive reviews of capital controls and exchange rates in emerging economies.

Note 3. See Bekaert \& Hodrick (2009) for exchange rate systems in our sample of emerging economies. We include Hungary in the sample of managed floating currencies as the Hungarian forint maintains a target zone to the euro but remains floating against the US dollar for our sample period.

Note 4. See, e.g., Magud et al. (2011) and IMF (2011b) for surveys on various measures of capital controls imposed in these countries.

Note 5 . The euro zone is treated as one country. 